\title{
E-Commerce in France: \\ Did Early Adoption Prevent the Development?
}

Eric Brousseau

FORUM, University of Paris X

Eric@brousseau.info

$\underline{\text { www.brousseau.info }}$

This study is part of the Globalization and E-Commerce project of the Center for Research on Information Technology and Organizations (CRITO) at the University of California, Irvine. The study has been supported by a grant from the U.S. National Science Foundation (CISE/IIS/CSS).

The paper benefited from helpful comments by three anonymous referees and by the editors of the volume. The author is grateful to each of them. Usual caveats apply.

Address Correspondence to: Eric Brousseau FORUM, University of Paris X Bâtiment K, 200 avenue de la république F-92001 Nanterre Cedex, France Phone: Tel: (33) 01.40.97.59.22 Fax: (33) 01.40.97.59.07 ; eric@brousseau.info ; www.brousseau.info 


\begin{abstract}
France's early adoption of Minitel and EDI in the 1980s was both a stimulus and an inhibitor to Internet-based e-commerce. It hindered the adoption of the Internet, but it also created the conditions for a rapid catch up when France switched to the Internet in 1997. The French were already open to the use of IT, a dense network of online specialists and information service providers already existed, and many investments required to go digital were already made. On the other hand, by mid-2001 France was still far behind the early adopters of ecommerce over the Internet. This is because the French catch up was checked by the implosion of the Internet financial bubble in 2000. Secondly, many Internet-based business models did not fit the French distribution channels. These differences suggest that e-commerce paths of development can be differentiated among nations, because both needs and solutions differ. This conclusion goes against the conventional wisdom that e-commerce will lead to the emergence of an integrated global marketplace in which common commercial practices will be implemented.
\end{abstract}

\title{
Introduction
}

Conventional wisdom establishes a contrast among the early adopters of the Internet — and the related ecommerce practices — and the latecomers. The United States and Scandinavia are generally considered leaders that invent new technologies then related business methods, which will be adopted some months or years later by Western European countries and Japan, and then by emerging countries. According to that vision, it is essential to implement policies aimed at reducing that gap by stimulating the adoption of Internet standards and the development of e-business practices. Indeed, the digital economy is characterized by increasing returns of adoption resulting in a "winners-take-all" competition that guarantee a long-term competitive advantage to innovators or earlier adopters (Shapiro \& Varian, 1999).

The development of e-commerce in France seems to question that common wisdom. First, the Internet was not a necessary condition for its development. The spread of the Minitel— a simple-to-use, cheap, and low speed digital network designed for text-based information exchanges implemented on the telephone network enabled the early development of B-to-C e-commerce in the 1980s. By the end of the 1980s, EDI supported the development of many B-to-B e-commerce practices. Second, early adoption does not guarantee race winning. According to many indicators, e-commerce practices seem to be less intensive in France than in the U.S. and 
Scandinavia, or even in Great Britain or Germany (even if most indicators under-estimate French performances because they focus on Internet-based-on-line-ordering; Brousseau, 2000).

The traditional explanation for this French paradox is often "technological." The French remain behind because the Minitel (and to a lesser extent EDI) prevented the spread of the Internet. Lacking that platform, the French were unable to develop new methods of work and commerce, resulting in an underdevelopment of e-commerce. According to this line of analysis, the French backwardness does not challenge the common wisdom that the productivity gains raised by the Internet based commerce are so high that any adopter will soon experience a strong growth of e-commerce.

This paper argues that the actual story is more complex since many factors influenced the adoption of the Internet and e-business practices. Moreover, practicing of e-commerce has to be differentiated from practicing Internet-commerce. The factors that inherited the use of the Internet had not a systematic negative influence on the development of e-commerce.

France's early adoption of Minitel and EDI was both a stimulus and an inhibitor to Internet-based e-commerce. Earlier technologies stimulated learning phenomena and business process re-engineering, while they obviously delayed the adoption of the Internet. France's efforts to restructure its industry to respond to the challenge raised by the creation of the European single market explain the late adoption of the Internet as well. Moreover, French e-commerce seems to develop along a specific path explained by a contrasted pre-existing organization of the distribution channels and by specific needs. While in the U.S. new entrants were the major promoters of new commercial practices, based on a substitution of old tangible business models ("brick and mortar") by new digital models ("click and deliver"), e-commerce projects in France were mainly supported by traditional companies seeking to hybridize their tangible and intangible activities ("click and mortar"). This suggests that ecommerce paths of development should be compared in terms of contrasted shape rather than in terms of contrasted pace.

The first section of the paper describes the rise of e-commerce in France in the 1980s with the development of the Minitel and EDI technologies. The next section explains France's late adoption of the Internet. The third section describes the current development of e-commerce in France. The last section analyzes the specific features of French e-commerce path of development. 


\section{The Rise of E-Commerce in the 1980s: Minitel and EDI}

\section{A Media for B-to-C and B-to-B for SMES}

E-commerce started in France in the early 1980s when the Minitel system (Videotext) was launched. Due to the active diffusion policy of the French government and France Telecom (the monopolist Public Telecommunication Operator at that time), 84 percent of French businesses were operating at least one Minitel in 1990 - up from 39 percent in 1985, and around 100 percent today. Moreover, one-third of the population was able to access Minitel in 1990. By the late 1990s, the number of users of the Minitel system was 35 million, a little more than half of the French population, sustaining the development of active B-to-C and B-to-B ecommerce markets (Faverie, 1998).

During its infancy (1983-1987), Minitel was mainly dedicated to non-professional uses, but soon B-to-C ecommerce emerged, especially with the development of pornographic and dating services. Diffusion of information by governmental agencies was also very active, as were services provided by the press (Flichy et al, 1991). Due to the "Kiosque" system ${ }^{\mathrm{i}}$ that enabled micro-payments, barriers to entry in these markets were very low.

By the mid-1980s, with the increasing diffusion of Minitel and the development of new tariffs (enabling information service providers to charge higher prices, or to not charge at all), a whole set of B-to-B services developed. Three types of services developed: database access (e. g. confidential letters, financial analysis), relationship management with clients (ordering and after sale services), and enhanced services (e.g., freight exchange in the transportation industry, financial loan management dedicated to realtors or car dealers). These services were well adapted to industries in which small businesses dominated, because small firms were operating archaic information systems mainly dedicated to accounting and wage management. Minitel was, therefore, not interfering with sophisticated logistic, marketing, or ordering management systems. Large companies were using more sophisticated technologies, based on dedicated data networks or leased lines to access information service providers (Brousseau, 1991).

In addition, the spread of free Minitel terminals within the population enabled large and small companies to develop an important number of B-to-C services (around 25,000 services in 1995). The most popular services include banking-at-home, ticketing and travel reservations, specialized information services (finance, health, travel and touring, etc.), and online ordering (mail order companies). Thanks to the Minitel system, consumers became used to online electronic services, resulting in a higher penetration rate of those services than in most European countries. ${ }^{\text {ii }}$ 
Until 1992, these new services developed at an impressive rate, but since then, the market has become stable. First, consumers' habits did not completely change, resulting in ceiling limits. For instance, mail order companies were able to rapidly take 15 percent of their orders online, but that percentage was never surpassed. Second, the Minitel was too antiquated to enable high-speed communication (especially images) and to support inter-computer exchanges of information (2,400 bit/s). Third, by 1996, the Internet became a competitor (Faverie, 1998). While stable until 1996, the traffic decreased (at a steady rate) from 84 millions hours of connection in 1996 to 54 millions in 2001(Mathonet, Kaplan [2002]).

However, the Minitel experience enabled the creation of a new industry of online services. Many of the current successful Internet-based start-ups migrated from Minitel to Internet. Large companies and governmental agencies began to transform their Minitel services into Internet services by the late 1990s. Indeed, developing on-line services requires investments in integrated and computerized databases, in back-office systems to link the public interface with the marketing-production applications, in the design of specific business methods and marketing concepts, in the development of trademarks and commercial reputation. By the mid 1990's many French firms had already made these investments. They had accumulated experience in running on-line services, as well. While switching to the Internet required to invest in a new front-office technology, and sometimes implied to implement new applications - e.g. on-line payment because the Kiosque system is not any longer available - , or even to modify the commercial concept - because the Internet can support innovative marketing methods such as "free" services —, the firms that were operating Minitel services benefited from their initial investments.

\section{EDI: A Technology for Large Companies in Specific Industries}

EDI took off in the late 1980s. Again, France Telecom played an important role in the popularization of EDI, but the main developments remained in the hands of user industries and of specialized service companies like General Electric Information Services. The major efforts occurred in industries in which implementing just-intime processes was essential. In the automotive industry, a strong standardization effort under the GALIA and the ODETTE committees occurred ${ }^{\text {iii }}$. The automakers and their suppliers not only standardized communication protocols, but they standardized business processes as well (Brousseau, 1994). The same occurred in the retailing and wholesaling industry. In 1999, Euro 122 billion was exchanged via EDI (62.5 percent in the distribution industry, and 25 percent in the automotive industry) (Observatoire du Commerce et des Échanges Électroniques, 1999). EDI is, therefore, heavily concentrated in two industries.

The concentration of EDI commercial transactions within two industries does not mean that EDI did not develop in other industries. In fact, especially for sizable companies, EDI is quite intensively used in French industry, but 
not usually for ordering online. EDI mainly supports the management of cooperative processes between industrial or commercial partners, and it is used to exchange documents with banks and public agencies (while 76 percent of French firms use EDI with business partners, only 35 percent take orders online; source Feuvrier \& Heitzmann, 2000).

The development of the Minitel, and later of the EDI technologies, led to the emergence of e-commerce practices long before the rise of the Internet. Even if many applications migrated from these former platforms to the new one after 1997, French e-commerce practices continue to be significantly based on the Minitel and EDI technologies. Figure 2 shows that more firms are operating e-business through EDI systems than through websites. Moreover, Minitel is still alive, even for large companies.

It is also interesting to note that large firms use each of the three technologies more intensively. While this does not contradict the conventional wisdom that web and Videotext technologies are easier to manage than EDI for small firms, it shows that large firms have an intrinsic advantage in developing online applications because they can afford for the required skills and/or obtain economy of scale ; an that they consider these platform as complements, rather than substitutes.

\section{Please insert Figure 1 here}

\section{A Late Adoption of the Internet}

\section{A Contrasted Information Infrastructure}

In the mid-1990s, France was behind most developed countries in the development of its information infrastructure, with the noticeable exceptions of the telephone-telecommunication infrastructure and the Minitel (Table 1). Indeed, the former monopoly-France Telecom-invested deeply from the 1970s to the mid-1990s to build a dense and efficient digital infrastructure. The telephone network is now fully digitized and businesses benefit from large capacities on X.25 networks and ISDN (Table 2)

\section{Please insert Table 1 here \\ Please insert Table 2 here}

This efficient telephone-telecommunication infrastructure was clearly an inhibitor for the development of the Internet. Until the late 1990s, "end-to-end" digital network technologies were considered expensive for households (since Minitel was free and PCs were still costly by the mid-1990s) and unsafe for businesses (X.25 
networks were reliable and centrally administrated). They were also seen as competitors to the French and European network operators' approach of centralized digital networks, in which information and communication services are provided by a single service provider that coordinates network operators and information service providers (as was experienced with the so called "Value Added Service" (VAS); Brousseau \& Quélin, 1996)

Two other factors had a negative influence on the development of the Internet:

- The rate of home PC ownership was low (Table 1). This can be explained by the existence of the Minitel, by the success of Playstations, and by the relatively high price of PCs (in Europe as compared to the US). In comparison, professional PCs were (and still are) not significantly less diffused in France than in the U.S. ${ }^{\mathrm{v}}$.

- Cable networks were underdeveloped (Table 2). While a national (mostly fiber) cable network had been implemented in major French cities between the late 1980s and the mid-1990s, the good quality of the hertzian TV, government hostility toward commercial TV, and bad experiences by private investors combined to result in a weak supply of channels for cable television.

A major switch occurred by 1997, when French decided to massively adopt the new generation of ITs. Increasing returns of adoption and positive network externalities played a strong role, generating a virtuous loop between demand and supply.

- The Internet began to be massively adopted by the end of 1999 (Table 3). The French rate of equipment grew significantly faster than in most other countries ${ }^{\mathrm{vi}}$. Business users, in particular, almost succeeded in catching up with their foreign competitors (Figure 2).

- In cable and satellite TV, a virtuous loop was initiated in 1997 when some major companies started to invest heavily in television infrastructure and programming. Although France remains behind most of the countries with the same level of development, it facilitated the development of domestic broadband Internet ${ }^{\mathrm{vii}}$.

Despite strong growth, the late take-off — soon before the dot.com crash — prevented France, especially households, for making up for lost time. France remains behind the EU average, and far below Scandinavia and the U.S. in terms of Internet usage and equipment. In addition, while above the European average (note vi), the adoption of digital technologies by French remained less rapid than in Japan (Table 1). Can these be explained?

Please insert Figure 2 here

\section{Please insert Table 3 here}




\section{How Internet became recognized as a vector for e-commerce}

Until 1998 French did not really pay attention to the raise of the Internet and did not really invested in this new technology. France was recovering from a recession that occurred in 1993. Macroeconomics had, therefore, an influence over the industry's ability to invest in the Internet, and over the household's likelihood to spend money on new technologies. Moreover, until this date, French opinion leaders and citizens did not seriously consider the potential of the Internet in general, and of the Internet for e-commerce in particular.

E-business and the Internet were considered two separate phenomena.

- The progressive digitization of business activities was considered an already old and slow trend. Following the computerization of administrative, manufacturing, and business processes (from the late 1960s to the late 1980s), electronic networks were supporting a greater integration among business partners by relying either on EDI systems or integrated computers in network systems. E-business was considered a predominantly B-to-B phenomenon, linked to huge and slow processes of organizational change that had already started in many industries. To the French, with a complete set of efficient X.25, ISDN, leased lines, and fully digitized telephone network, developing an additional network did not seem necessary. Moreover, Minitels, as well as call centers and PCs connected to mainframes through the telephone network, were already available for B-to-C applications.

- The Internet was seen as a competing technical (and U.S. dominated) standard, and not as the architecture for the Information Society. The decentralization of the administration of the Internet was considered a disadvantage in terms of safety (as compared to X.25 networks) that hindered is use in e-business. The Internet was consequently considered as a U.S. competitor to the Minitel, not as a superior technology.

These opinions evolved in the late 1990's, when the development of the technology and the evolution of cryptographic regulations in OECD countries convinced most decision-makers and users that the Internet was becoming the platform of integration for digital technologies and information services.

Until 1998, the development of the Internet and of e-commerce was therefore clearly not an essential factor in governmental and industry policies. France had to prepare its integration in the Single Market, and then in the Euro system. The French "modernization" policy clearly addressed those issues as priorities. While this was essentially a macroeconomic policy issue, it had implications for more micro-economic policies, such as industrial policy and competition policy. The government focused its attention on the liberalization of the French economy, and on the strengthening of firms. A whole set of "deregulations" occurred, resulting in the 
internationalization of French firms, and the development of more efficient financial markets and industry governance systems.

This policy initiated favorable conditions to the raise of the Internet. Indeed, the French government led a process of deregulation and privatization in the telecommunication industry. In less than a decade, the Administration of Telecommunication was transformed into France Telecom, a dynamic, private telecommunication company, competing internationally. This policy led to the enrichment of the telecommunication services portfolio, and to rapid decreases in telecommunications prices.

In 1997 two events contributed to focus the attention of decision makers on the Internet: the raise of the competitive pressure and a renewed public policy.

In 1997 the French telecommunication market became fully competitive. In 1996, France Telecom was privatized and the Law on the Regulation of the Telecommunication Market was passed. It implemented a principle of generalized competition that became effective on January $1^{\text {st }} 1997$. The competitive pressure led France Telecom to develop an aggressive strategy on the new Internet market, and the former PTO became a strong support for its development, through its specialized subsidiary Wanadoo. Since then, access tariffs have been curved and competition began to develop.

By mid-1997, a new government came to power. He promoted the "Entry in the Information Society" as an essential axis of his policy for the modernization of France (Brousseau, $2002 \mathrm{~b}$ ) and identified the Internet as a key technology to be supported. The French government supported private initiatives rather than directly operating or subsidizing operators. It regulated ISPs' conditions of interconnection to fuel competition and lower tariffs. It also stimulated initiatives by private companies and local authorities favoring start-ups. It adapted the French legal system, while because of the development of X.25 networks and the Minitel, many French laws had already been reshaped. However, the main aspect of French policy was promotion. The government tried to convince the business world, its own agencies, and opinion leaders that it was essential for them to deeply invest in the Internet and related technologies and services. The French efforts were closely aligned with the EU policy that shares common aims and methodology (http://europa.eu.int/information_society/eeurope/index_en.htm).

\section{Complementary platforms to trade on-line}

These strong efforts to switch to the Internet did not led however to abandon more traditional technologies; resulting in a pluri-platform e-Commerce. Internet is characterized by different (sometimes new) capabilities to those provided by the traditional platforms. Firms have therefore been benefiting from a portfolio of alternative techniques and networks, which enabled them to deploy tailored e-commerce capabilities either by choosing the 
most appropriate platform, or by mixing them. While those that have been relying on alternative techniques did not benefited, neither from the high pace of innovation that characterized the Internet in the late 1990's, nor from its wide inter-operability and its extended connectivity (e.g. global market), they have been benefiting from alternative advantages (such as the wide diffusion of the Minitel, or the security provided by EDI). The complementarily among the platforms lies also in the fact that various categories of players have contrasted access to them. Consequently, the Internet substituted only partially to the pre-existing platforms, and was often used in conjunction with them

A significant gap exists between large professional users - whose behavior is very similar to most global firms, and therefore whose management and commercial practices rely intensively on ICTs — and customers or small firms who do not use ICTs so intensively. Table 4 and Figure 3 illustrate this.

The penetration of various ICTs in the industry (Figure 3), shows that French firms use a wide set of technologies and that the level of equipment was already high in 1999. Internet adoption rates were roughly the same as the use of PCs and mobile phones, and significantly higher than the use of EDI, ERP, and the development of specific websites by companies. Figures 2 and 3 show, therefore, that by late 1999, French businesses had already switched to the Internet, but that most advanced uses of Internet and related techniques were still in their infancies, and concentrated in large firms. In particular:

- Internet connections do not automatically mean website and online transactions. Online transaction rates remain low (10 percent of firms on average). Moreover, we do not know the actual share of online orders on sales (See Figures 1 and 3).

- Not surprisingly, large and international firms that belong to groups, are innovative, and are involved in the high tech industries (Table 4) perform most advanced uses of ICTs.

Behind French poor average performance in the use of the Internet, there are quite contrasted behaviors in term of intensity and sophistication of uses. The resulting digital divides impacted on the pace, and then rate, of adoption, as it will be argued later.

Please insert Figure 3 here

$\underline{\text { Please insert Table } 4 \text { here }}$ 


\section{Diffusion of E-Commerce}

It is difficult to measure e-commerce, because the measured categories and the methods to measure them are evolving quite rapidly (Brousseau, 2000). Assessments based solely on online ordering do not take into account the actual impact of the Internet on the performance of markets, because of the importance of "brick-andmortar" models (Brousseau, 2002 a). For example, only 2 percent of U.S. car sales occur over the Internet, but, according to various studies, the Internet plays a role in about half of the transactions (Scott Morton et al, 2000).

In France, like in the U.S., B-to-B e-commerce seems to account for approximately eight times more than B-to$\mathrm{C}$ e-commerce (Table 5). These figures have to be discussed because for France, as for many countries, the assessment of e-commerce volume varies from one to ten, depending on the consulting firm (OECD, 2000). Whatever the accuracy of these figures, in France, experts agree that B-to-B e-commerce and B-to-C ecommerce differ greatly (Brousseau, 2000).

- B-to-B e-commerce is generally not performed on the Internet. The bulk of exchanges are performed via EDI systems and via Minitel (for small businesses), even though many applications are migrating toward the Internet (Figure 2). Most systems are dedicated to the management of the ex-post phases of the transaction (after the deal has been made; see figure 1 and related comment). Digital networks do not yet support electronic brokerage or digital markets; they support cooperative processes and exchanges of information necessary for the delivery of services (whose conditions of exchange were settled off-line). Electronic marketplaces are still in development, while major French companies are involved in most global initiatives.

- B-to-C e-commerce is mainly performed over the Internet, but significant share remains based on the Minitel system. B-to-C e-commerce systems essentially focus on the ex-ante operations of the transaction (research and negotiation). The types of markets that are already significantly developed are the same as in the U.S., except for cars, apparel and fashion, and gifts (Table 9). These exceptions are due to the specific organization of the French distribution system and to the French organization of urban space (see below).

\section{Please insert Table 5 here}

Please insert Table 6 here 
As in the U.S., these figures must be compared with those of the whole market (table 5). In the U.S., online orders account for 7 percent of the book market, 6 percent of the CD market, and 3.7 percent of the ticketing and gaming markets. These shares are even lower in France. For instance, the FF 620 million travel and lodging market accounts for only 0.3 percent of the total French market. While the pace of evolution is quite dynamic, it is clear that B-to-C e-commerce still represents only a minute share of retail sales (Bureau d'Information et de Prévision Economique, BIPE, 2000) and that the numerous digital bankruptcies that occurred in 2001-2002 affected enthusiasm about e-commerce.

Among the factors explaining the weak development of B-to-C Internet-based e-commerce in France as compared to the U.S., it is important to note the organization of the distribution system.

- In France, cities are denser and more mono-centric than U.S. "hedge cities" (i.e. cities without an actual and single city center). The population is concentrated around city centers where shopping facilities are widely available, and provide customers with diversified services and a convenient means to access them. Demand for at-a-distance commerce is therefore less important than in the U.S. Moreover, home delivery is complex (and costly) to organize in city centers (Rallet, 2001).

- In addition, huge integrated and pluri-functional supermarket chains distribute almost all categories of consumer goods and services. Consumers do not call for online commerce, because going to a supermarket allows them to gather their products as well as other services at a single counter (Moati, 2000).

B-to-C e-commerce seems, therefore, to be a niche market. However, there are opportunities for the development of new type of services based on the customized assembling of information intensive services (Gensollen, 2001) or value-added services mixing the advantages of traditional and online retailing (Brousseau, 2002 a). French supermarket chains are currently investing in the development of "points of delivery" in large cities, where consumers can conveniently pick up their online ordered items, and where they can be provided with additional services (e.g., fine food, take-out, dry-cleaning, banking, and other services).

While in the U.S. new entrants were the major promoters of new commercial practices, based on a substitution of old tangible business models ("brick and mortar") by new digital models ("click and deliver"), e-commerce projects in France were mainly supported by traditional companies seeking to hybridize their tangible and intangible activities ("click and mortar"). While this last model is on the verge of becoming the dominant model in the U.S., it is clear that in France, as in Japan, the e-commerce path of development does not resemble the U.S. path. Differences in the spatial distribution of the populations and in the organization of cities result is different constraints for the organization of commerce, and therefore of e-commerce. 


\section{A French Style for E-Commerce?}

When French data about Internet adoption or online sales are compared to U.S. or Scandinavian data, the usual interpretation is to consider France a follower in the digitization of its economy and commerce. While this vision is not completely wrong, it is not completely right either. Indeed, the French were the first to experiment at the actual scale with B-to-C, and they were not far behind the U.S. in the implementation of EDI. Even if the Internet is in many respects a superior and more flexible technology, the Minitel and EDI are still efficient tools to support e-commerce. What is the explanation, then, for why the French seem to lag behind the U.S. and Scandinavia in e-commerce development? To answer, Internet adoption has to be distinguished from the use of digital networks to support commerce. Indeed, France is really behind the US and Scandinavia when one consider Internet-based-on-line-ordering. Whether France is behind in the use of electronic and digital technologies in commerce remains a more open question since France seem to be on a different path of development.

\section{The Minitel (and EDI), the Internet and e-commerce}

France is a poor user of the Internet as compared to most other developed countries. This is surprising since France benefited from many favorable conditions:

- Its population is wealthy and well educated, and the rate of digital literacy is high - while below the US and Scandinavia-, since ICTs are common in the professional environment and since the Minitel, videogames, and mobile phones popularized their use. Moreover, France enjoys an excellent telecommunication infrastructure.

- Its past experiences created a milieu of online service specialists. In addition, the fixed costs of the development of French speaking services can be covered by the relatively large size of the population speaking French in Europe and overseas (150 millions people worldwide).

France should have had therefore quickly switch to the new technology since many learning and organizational investments required by the digital economy were already done. To most French, the Internet remained however a questionable technology until late 1997. While since then, vigorous public and private catch up efforts occurred, the lateness of the digital take-off (soon before the implosion of the "Internet Bubble") partly explains why France remains behind the U.S. and Scandinavia. Another factor is the too slow pace of digitization that prevented catching-up. 
Were the Minitel and EDI the main causes for this late recognition and too slow rate of adoption of the Internet? The availability of these alternative technologies obviously hindered users to switch to the Internet, since it did not seemed to support new useful functionalities at the time it was launched. However, firms that use the Internet intensively are the more intense users of Minitel as well. Moreover, many sociological analyses suggest that the early individual adopters of the Minitel were the early adopters of the Internet as well (Flichy, et al, 1991). The Minitel was an inhibitor to the early diffusion of the Internet in the population of moderate users, but it constituted a gateway to the digital world for the most advanced users. Moreover, the Minitel is a complement rather than as a substitute to the Internet. For instance, it is accessible and used even in the less digitized segments of the population. This is a good way to provide less educated people and the elderly with online services $^{\text {viii }}$. The Minitel is, therefore, not solely responsible for the late entry of France in the Internet.

The macroeconomic climate had also an impact on the late take-off. Liberalizing the French economy and going international were priorities in the policy and business agendas until the late 1990s. Sustaining the diffusion of ICTs clearly ranked second. Since in addition France faced a recession by the mid-1990, the French ability to invest in the Internet was low when the technology became available. Lastly, the specialization of the French ICT industry in the traditional telecommunication technologies misled investors and users.

Digital divides, on the other hand, explain largely the too slow pace of Internet adoption by the end of the period. Inequalities generate several digital divides among the most educated and the less, Paris and the rest of France, large firms and SMEs, modern and archaic industries, etc. Professional users are not significantly less "netized" than foreign businesses, while the rate of Internet adoption by French households rank quite low. A huge contrast differentiates large and small firms. A wide divide exists among households (see note viii) and additional divides are documented in Brousseau [2002 b]. These divides are clearly inhibitors to the adoption of Internet (and related practices such as e-commerce). Since many citizens, workers, businesses cannot interact digitally with their partners (that are not digitized), many potential adopters decide to delay adoption. It can then be theorized that France is still in the first phase of the S-shaped curve that characterizes the diffusion of most network technologies (i.e., slow rate of growth due to a ceiling effect, followed by a high rate of growth due to positive network externalities, followed by a slow rate of growth due to saturation).

Due to this combination of causes, French, especially French households, are less intensive users of the Internet, and therefore of the Internet-based-e-commerce. This does not mean, however, that e-commerce practices are not developed, and that they were hindered by the experience of the Minitel. The Minitel experience, together with other factors, led France to follow a specific path of digitization that had an impact over the type of practices that are implemented on-line. 


\section{An hybridization between digital and traditional channels}

In addition to the weak diffusion of the Internet, other factors seem to hinder the development of Internetcommerce models based on B-to-C online sales and on electronic market place for B-to-B.

- France is characterized by a dense distribution network of efficient supermarket chains and specialized stores. B-to-C e-commerce channels, therefore, have to compete among a preexisting establishment.

- French industry is organized around large companies maintaining long-term co-operative relationships with networks of smaller firms that supply them in goods and services. In the recent past, these cooperative networks have been reinforced both because externalization policies led large firms to rely more intensely on specific services delivered by their partners, and because internationalization led to alliances with foreign counterparts. The e-commerce model able to support this type of relationship resembles more the EDI exchanges of post-contractual information coordination, rather than the electronic marketplaces based on the principle of blind auctions.

In the B-to-C segment, e-commerce is not expected to radically transform the structure of the distribution industry. The industry is expected to consolidate towards brick-and-mortar models, which will be dominated by traditional distribution companies that consider the Internet an additional channel to market and advertise their products or services. E-commerce sites will essentially enable these companies to provide their customers with additional and customized pre-sale or after-sale services. Online ordering and at-home delivery is not considered the primary advantage of e-commerce (Licoppe, 2001) ${ }^{\mathrm{ix}}$. However, online distribution will become essential for information-based goods and services. French book publishing companies, the press, and service companies are expected to be major players in providing services to the French-speaking world.

B-to-B e-business is, for the moment, concentrated in the automotive and distribution industries, where aftersale operations are performed though digital networks. In these two industries, EDI enabled productivity gains due to higher turnover and just-in-time management of demand. This did not lead, however, to more competitive markets. On the contrary, integration among suppliers and major firms is reinforced because to guarantee an efficient quality of services, long-term cooperative relationships have to substitute for spot transactions.

Most major French firms are participating in the various international alliances that are currently creating marketplaces. The conventional wisdom about these marketplaces is that they are appropriate mainly for the exchange of standardized products and services. As long as companies need specific inputs, they will continue to develop long-term cooperative relationships with a reduced number of partners. 
Therefore, e-commerce is expected to generate two types of differentiated effects. When applied to standard goods or services, marketplaces should make markets more transparent and reinforce price competition, leading to substantial productivity gains and major restructuring of industries at the worldwide level. When applied to customized and specific goods and services, EDI type systems will enable business partners to cooperate more efficiently only if they are able to maintain long-term cooperative relationships. While both should lead to productivity gains, the dynamic of the two trends is quite different, and the second effect will not have a strong impact on the existing structure of French industry, since it is already based on long-term, cooperative, interfirm relationships.

One of the conclusions that can be drawn from e-commerce development in France is that the usual statistical indicators used to analyze the development in various countries could be misleading. This is because they assume that the Internet is the exclusive technology for e-commerce, and because they rely on the idea that all the countries are following a similar path in developing the same e-commerce model. France, together with some other "non-standard" developed countries like Japan, might demonstrate that there are several ways to enter the information society. The shape of e-commerce could vary among countries depending on the preexisting organization of distribution channels and inter-firm relationships. 
Figure 1: The Rise of E-Commerce in France

(Percent of businesses performing online operations in 1999)

(Population: Manufacturing businesses with more than 20 employees, except agro-food industry)

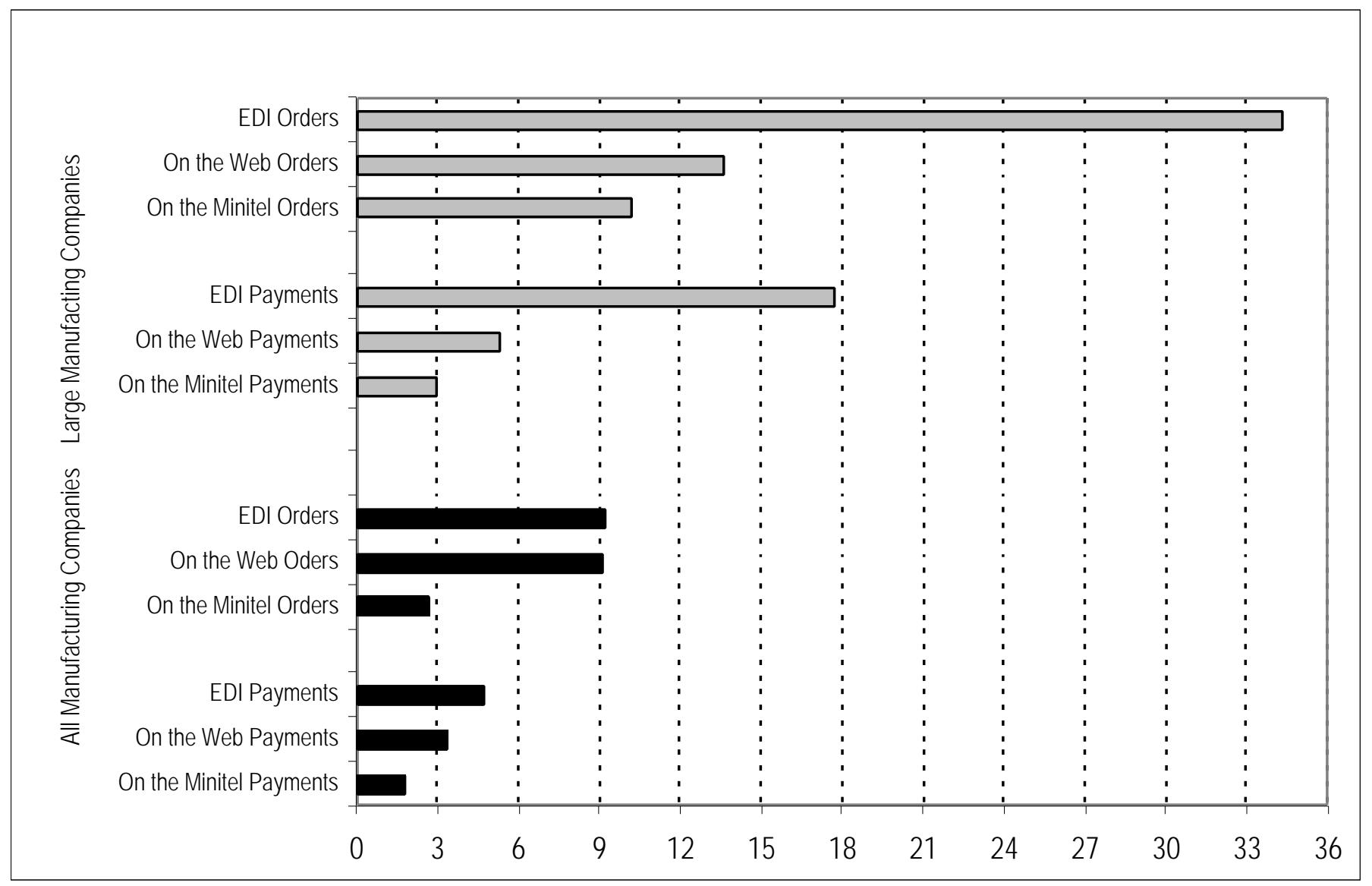

Source: Feuvrier \& Heitzmann, 2000. 
Table 1: Evolution of the E-Commerce Infrastructure (in millions of units)

\begin{tabular}{|l|c|c|c|c|c|c|c|c|}
\hline \multirow{2}{*}{ Technologies } & \multicolumn{2}{|c|}{ France } & \multicolumn{2}{c|}{ EU 15 } & \multicolumn{2}{c|}{ USA } & \multicolumn{2}{c|}{ Japan } \\
\cline { 2 - 9 } & 1995 & 1999 & 1995 & 1999 & 1995 & 1999 & 1995 & 1999 \\
\hline PCs & 7.8 & 13.0 & 56.2 & 93.2 & 86.3 & 141.0 & 15.1 & 36.3 \\
per 100 population & 13 & 22 & 15 & 25 & 33 & 52 & 12 & 29 \\
\hline Internet hosts & 0.15 & 0.6 & 1.8 & 8.5 & 6.0 & 53.1 & 0.26 & 2.6 \\
per 100 population & 0.3 & 1.0 & 0.5 & 2.3 & 2.3 & 19.6 & 0.2 & 2.1 \\
\hline Internet users & $1.0^{*}$ & 5.6 & $19.3^{*}$ & 55.9 & $40.0^{*}$ & 110.0 & $11.5^{*}$ & 18.3 \\
per 100 population & $1.7^{*}$ & 9.6 & $5.2^{*}$ & 14.9 & $15^{*}$ & 40.5 & $9.3^{*}$ & 14.5 \\
\hline Cellular phones & 1.0 & 21.4 & 21.1 & 146.5 & 33.7 & 86.0 & 1.7 & 56.8 \\
per 100 population & 1.8 & 36.3 & 5.7 & 39.1 & 12.9 & 31.7 & 9.3 & 45.0 \\
\hline
\end{tabular}

$* 1997$

Source: Eurostat, 2001. 
Table 2: Telecommunications Infrastructure

\begin{tabular}{|l|c|c|c|c|c|}
\hline & $\begin{array}{c}\text { Telecom } \\
\text { investment as } \\
\text { \% of GDP, }\end{array}$ & $\begin{array}{c}\text { Main phone } \\
\text { lines per } \\
1,000 \\
\text { population, }\end{array}$ & $\begin{array}{c}\text { Cell phone } \\
\text { subscribers per } \\
1,000 \\
\text { population, }\end{array}$ & $\begin{array}{c}\text { CATV } \\
\text { \% Digital } \\
\text { phone lines, } \\
\text { subscribers } \\
\text { per } 1,000 \\
\text { population } \\
1999\end{array}$ \\
\hline France & 1999 & 1999 & 1999 & 98.0 & 49.25 \\
United States & 0.49 & 581.71 & 365.63 & 91.6 & 251.34 \\
European Union & 0.28 & 673.00 & 315.55 & 97.1 & 111.49 \\
Scandinavia & 0.61 & 537.62 & 400.28 & 100.0 & 129.64 \\
OECD & 0.71 & 653.00 & 583.66 & 93.8 & 140.02 \\
\hline
\end{tabular}

Source: International Telecommunication Union, 2001. 
Table 3: The Evolution of the Information Infrastructure

\begin{tabular}{|c|c|c|c|c|c|c|}
\hline Categories & 1995 & 1996 & 1997 & 1998 & 1999 & 2000 \\
\hline Cell phone subscribers per 1,000 pop. & 22,52 & 42,44 & 99,94 & 191,96 & 365,63 & 494,09 \\
\hline Internet hosts per 1,000 pop. & 2,61 & 4,08 & 6,1 & 8,75 & 21,03 & 19,09 \\
\hline Internet users per 1,000 pop. & 16,42 & 25,85 & 42,95 & 63,36 & 91,61 & 144,56 \\
\hline PCs per 1,000 pop. & 134,84 & 151,65 & 163,2 & 193,5 & 221,77 & 304,76 \\
\hline
\end{tabular}

Sources: International Data Corporation, 2000; International Telecommunication Union, 2000; 
Figure 2: The Temptative Internet Catch-up by French Businesses $\%$ of Companies with an Internet Access

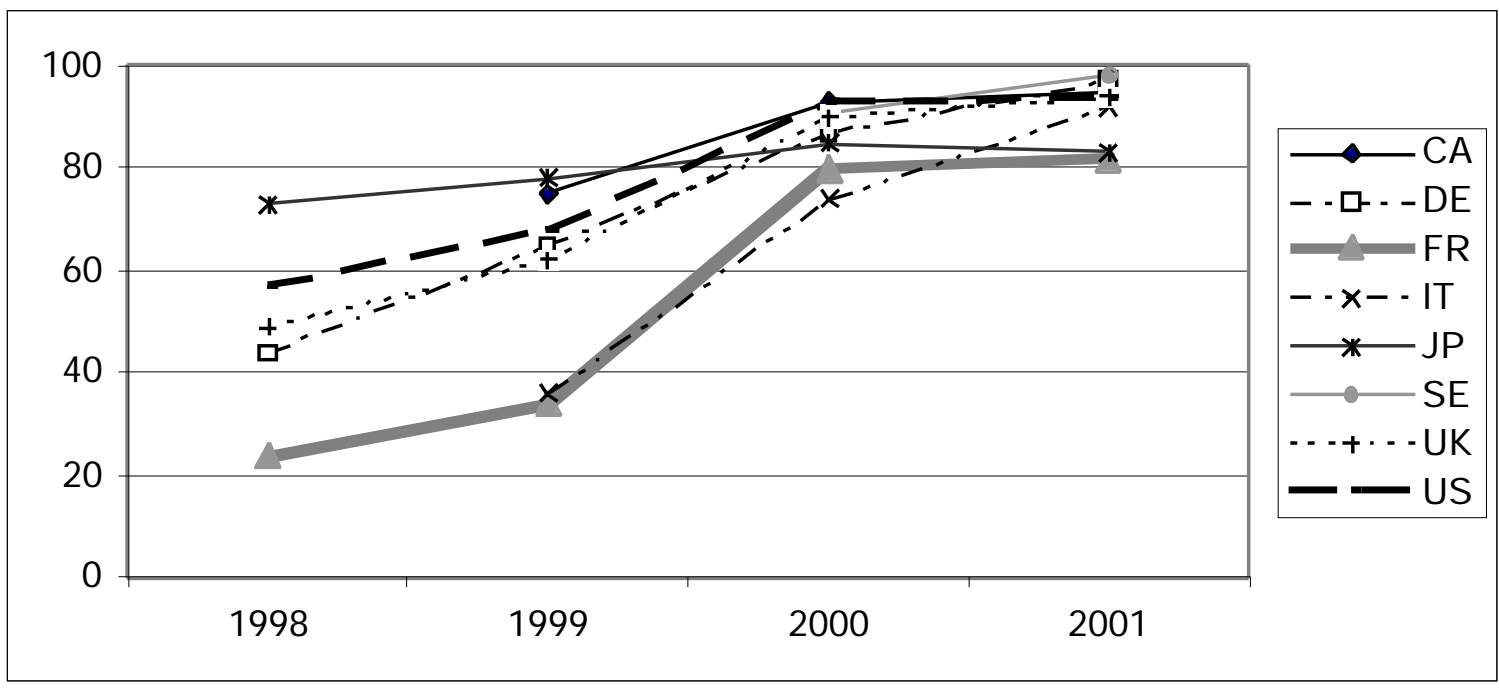

$\%$ of Businesses with a WebSite

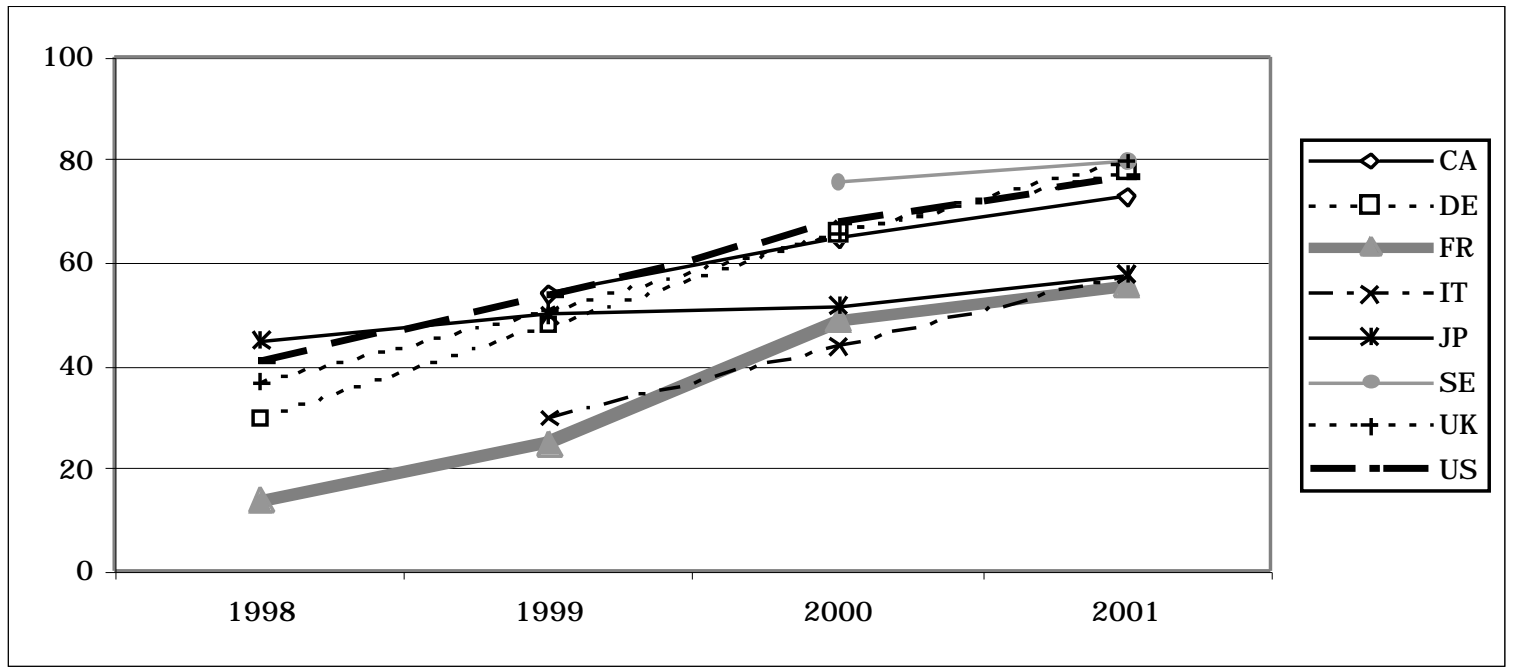

Source DTI International Benchmarking Study 2001, Quoted by Mathonet \& Kaplan, 2002 
Figure 3: Equipment in ICTs in French Manufacturing Firms

(Percent of firms. Firms are grouped by number of employees.)

Source: Feuvrier \& Heitzmann, 2000.

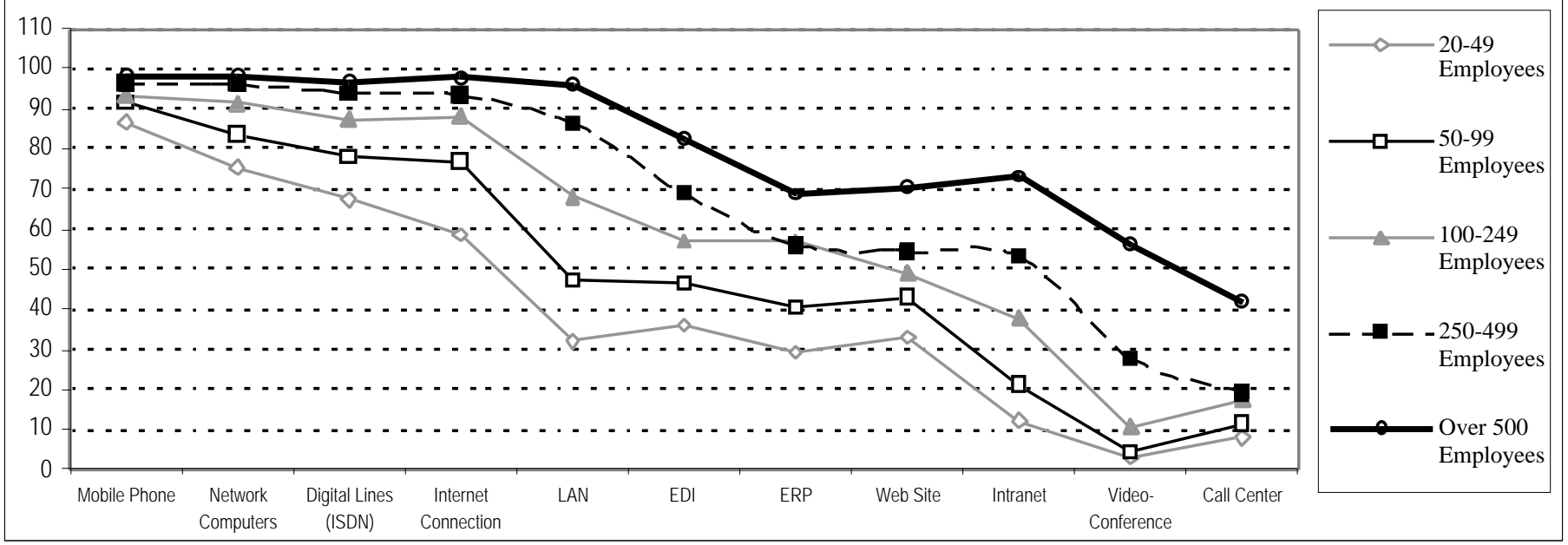


Table 4: Equipment in ICTs in French Manufacturing Firms in 1999 (Percent of firms using various ICTs in each category of firms)

\begin{tabular}{|l|r|r|r|r|r|}
\hline Type of Firm & $\begin{array}{c}\text { Internet } \\
\text { Connection }\end{array}$ & Website & $\begin{array}{c}\text { Online } \\
\text { Order }\end{array}$ & Intranet & Extranet \\
\hline Large Firms & 97.7 & 70.5 & 13.6 & 79.1 & 37.2 \\
Small Firms & 67.6 & 38.1 & 8.9 & 19.3 & 8.6 \\
\hline High Tech & 85.6 & 51.5 & 9.2 & 36.5 & 16.8 \\
Low Tech & 64.3 & 36.2 & 8.9 & 17.4 & 7.8 \\
\hline Export > 25\% of Sales & 83.0 & 52.4 & 10.2 & 33.4 & 16.7 \\
Export < 25\% of Sales & 64.0 & 35.0 & 8.6 & 17.3 & 7.3 \\
\hline Group 's Subsidiary & 82.1 & 47.9 & 9.5 & 38.4 & 15.8 \\
Independent Firms & 59.2 & 33.3 & 8.6 & 9.5 & 5.3 \\
\hline Innovating Company & 80.5 & 49.6 & 11.1 & 28.6 & 13.2 \\
Non Innovating Company & 58.7 & 30.5 & 7.3 & 15.2 & 6.6 \\
\hline
\end{tabular}

Source: SESSI, (Service des Etudes et des Statistiques industrielles), 2001a. 
Table 5: E-Commerce

\begin{tabular}{|l|r|r|r|r|r|}
\hline \multicolumn{1}{|c|}{ Region } & $\begin{array}{c}\text { Secure servers per } \\
100,000 \text { population } \\
2000\end{array}$ & $\begin{array}{c}\text { Secure servers with } \\
\text { strong encryption } \\
\text { per 100,000 } \\
\text { population }\end{array}$ & $\begin{array}{c}\text { B2B trade in } \\
\text { US\$M }\end{array}$ & $\begin{array}{c}\text { B2C trade in } \\
\text { US\$M }\end{array}$ & $\begin{array}{c}\% \text { E-Commerce } \\
\text { Sales of GDP } \\
20000\end{array}$ \\
\hline France & 2.67 & 1.25 & $\$ 6,170.95$ & $\$ 1,119.60$ & .500 \\
United States & 28.30 & 25.11 & $\$ 118,457.20$ & $\$ 44,084.29$ & .57 \\
Scandinavia & 9.16 & 5.53 & $\$ 6,127.71$ & $\$ 1,519.30$ & 1.63 \\
EU & 4.98 & 3.18 & $\$ 53,734.62$ & $\$ 11,735.30$ & .14 \\
OECD & 10.09 & 8.39 & $\$ 268,500.30$ & $\$ 69,146.65$ & .84 \\
\hline
\end{tabular}

Sources: Netcraft, 2002; Forrester Research, Inc., 2000; Sofres, 2000., IDC, 2002 
Table 6: Distribution of the B-to-C E-Commerce Market in 1999

\begin{tabular}{|l|c|r|r|r|}
\hline \multirow{2}{*}{ Market } & \multicolumn{2}{|c|}{ France } & \multicolumn{3}{c|}{ US } \\
Travel \& Lodging & FF billion & \% of total & \$ billion & otal \\
Computers \& Software & 620 & 47.18 & 7,798 & 38.33 \\
Books / CDs / Video & 312 & 23.74 & 4,455 & 21.89 \\
Apparel \& Fashion & 137 & 10.43 & 2,376 & 11.67 \\
Flowers / Gifts & 5 & 0.38 & 1,620 & 7.96 \\
Food \& Drinks & 15 & 1.14 & 656 & 3.23 \\
Health / Beauty & 33 & 2.51 & 513 & 2.52 \\
Furniture / Consumer Electronics & - & - & 509 & 2.50 \\
Ticketing & 25 & 1.90 & 446 & 2.19 \\
Gaming / Gambling & 7 & 0.53 & 300 & 1.47 \\
General (mail order, malls, etc.) & 2 & 0.15 & 253 & 1.24 \\
Various & 92 & 7.00 & - & - \\
\hline Total & 66 & 5.02 & 1,418 & 6.97 \\
\hline Sources: Benchar & $\mathbf{1 0 0 . 0 0}$ & $\mathbf{2 0 , 3 4 4}$ & $\mathbf{1 0 0 . 0 0}$ \\
\hline
\end{tabular}

Sources: Benchmark Group, 2000; Forrester Research, 2000. 


\section{REFERENCES}

Benchmark Group. 2000. Le commerce Electronique sur l'Internet en France - 2000. Paris: Benchmark Group. <http://www.benchmark.fr>

Brousseau, E. 1991. Telematics and professionals: From the absence of discrimination to the limitation of uses. In European Telematics, The Emerging Economy of Words, eds. P. Flichy, J. Jouët, and P. Beaud, pp. 3-59. North-Holland, Amsterdam.

Brousseau, E. 1994. EDI and inter-firm relationships: Toward a standardization of co-ordination processes? Information, Economics and Policy 6(3-4):319-347.

Brousseau, E. 2000. Commerce electronique: Ce que disent les chiffres et ce qu'il faudrait savoir. Economie et Statistiques 339-340 (2000-9/10):147-170 (English translation at www.insee.fr)

Brousseau, E. 2002 a. The governance of transaction by commercial intermediaries: An analysis of the reengineering of intermediation by electronic commerce. International Journal of the Economics of Business 8(3), 2002.

Brousseau, E. 2002 b. "Globalization and E-Commerce: The French Environment and Policy", Report for the Center for Research on Information Technology and Organizations (CRITO), University of California at Irvine, and the U.S. National Science Foundation (CISE/IIS/CSS), Globalization and E-Commerce Project

Brousseau, E., and Quélin, B. 1996. Asset specificity and organizational arrangements: The case of the new telecommunications services market. Industrial and Corporate Change 5(4) (December):1205-1230.

Bureau d'Information et de Prévision Economique (BIPE). 2000. Bonjour la nouvelle économie! Les enjeux prospectifs de la révolution numérique. Paris : BIPE.

EcaTT. 2000. Benchmarking progress on new ways of working and new form of business among Europe. Report for the IST Program, European Commission, D. G. Information Society, Brussells $<$ http://www.ecatt.com> August.

ESIS (European Survey of Information Society Projects and Actions). 2000. Basic Facts \& Indicators, European Union, 2000, <http://europa.eu.int/ISPO/esis> November.

Faverie. 1998. France's experience with the minitel: Lessons for electronic commerce over the Internet. OECD, Working Party on the Information Economy. DSTI/ICCP/Ie 97 (10 October).

<http://www1.oecd.org/dsti/sti/it/infosoc/prod/minitel.htm>

Feuvrier, P., and Heitzmann, R. 2000. Informatique et télécommunications dans l'industrie Française, des entreprises de plus en plus communicantes. Le 4-Pages des Statistiques Industrielles. SESSI (Service des Etudes et des Statistiques industrielles), Ministère de l'Economie des Finances et de l'Industrie (Census Bureau from the French Ministry of Economic, Financial and Economic Affairs) 137(August):1-4.

Flichy, P., Jouët, J., and Beaud, P. Eds. 1991. European telematics, the emerging economy of words, pp. 33-59. Amsterdam: North-Holland. 
Forrester Research, Inc. 2000. Global E-Commerce Model. <http://www.forrester.com/Home/0,3257,1,FF.html>

Gensollen, M. 2001. Internet: marché électronique ou réseaux commerciaux? Revue Economique, [special issue] "Economie de l'Internet," eds. E. Brousseau and N. Curien. October, 52, 97-118

Greenan, N. 1999. "Technologies de l'informationet de la communication, productivite et emploi: deux paradoxes," in Brousseau, E., and A. Rallet, eds., Technologies de l'Information, Organisation et Performances Economiques. Paris: Commissariat Général du Plan, September, www.brousseau.info 75-159.

Heitzmann, R., and. Loué J.F. 2001. L'Internet: Les Français se hâtent lentement. Le 4-Pages des Statistiques Industrielles. SESSI (Service des Etudes et des Statistiques industrielles), Ministère de l'Economie des Finances et de l'Industrie (Census Bureau from the French Ministry of Economic, Financial and Economic Affairs) 152 (August):1-4.

International Data Corporation, 2002, Internet Commerce M arket M odel, Version 8.1

International Data Corporation. 2000. The 1999 IDC Worldwide Black Book.

International Telecommunication Union, 2001, Yearbook of Statistics. Geneva: International Telecommunication Union.

Licoppe, C. 2001. Pratiques et trajectoires de la grande distribution dans le commerce alimentaire sur internet: vers un autre modèle de coordination pour le commerce électronique? Revue Economique, special issue, "Economie de l'Internet," eds. E. Brousseau and N. Curien. October, 52, 191-212

Mathonnet P., Kaplan D. 2002, Tableau de bord du commerce électronique, Mission pour l'Economie Numérique, Ministère de l'Economie des Finances du Commerce et de l'Industrie, Avril, http://www.men.minefi.gouv.fr/webmen/informations/tabord/tabord200204.pdf

Moati, P. 2001. L' avenir de la grande distribution. Editions Odile Jacob. Paris.

Netcraft, 2002, http://www.netcraft.com

NetValue. 2001. http://www.netvalue.fr

Observatoire du Commerce et des Échanges Électroniques. 1999. Les Chiffres clés du Commerce électronique. $<\mathrm{http}: / /$ www.edifrance.org/>

OECD. 2000. The Economic and Social Impacts of Electronic Commerce: Preliminary Findings and Research Agenda. 〈http://www.oecd/e_commerce/summary.htm>

Rallet, A. 2001. Commerce électronique et localisation urbaine des activités commerciales. Revue Economique, [special issue] "Economie de l'Interne,t" eds. E. Brousseau and N. Curien. October, 52, 267-290

Shapiro, C., and H.R. Varian. 1999. Information and Rules. Cambridge: Harvard Business School Press. 
Scott Morton F., Zettelmeyerf, F., and Risso, J. 2000. Internet Car Retailing. Mimeo. Yale University and NBER.

SESSI (Service des Etudes et des Statistiques industrielles). 2001a. On-line Statistics, August. <http://www.finances.gouv.fr/minefi/chiffres/index.htm>

SESSI (Service des Etudes et des Statistiques industrielles). 2001b. Tableau De Bord de l'Innovation. 5th ed. Ministère de l'Economie des Finances et de l'Industrie (Census Bureau from the French Ministry of Economic, Financial and Economic Affairs), April.

Taylor Nelson Sofres. 2000. Global E-Commerce Report. <http://www.tnsofres.com/>

\footnotetext{
${ }^{\mathrm{i}}$ Part of telecommunication charges are paid by the telecommunication operator to the information service provider; telecommunications charges, whether they correspond to the communication or the information services, are charged to customers on their France Telecom bill.
}

ii 20 percent of the population was a regular or occasional online shopper in 1999, and 35 percent are projected to do so by 2001 (EU-10 average was 14 percent, and is projected to be 28 percent) (EcaTT, 2000).

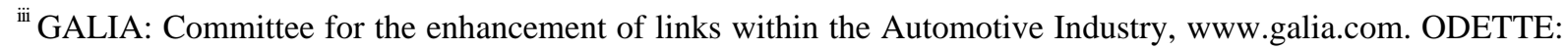
Committee for the organization of EDI in Europe, www.odette.org.

${ }^{\text {iv }}$ The French IT industry is specialized in telecommunications and electronics (except consumer electronics), while the U.S. industry is the worldwide leader in computers and software, the basis of the Internet. Diffusion between the digital industry and other industries was less intense in France than in the US. Moreover, French firms and governments were more focused on traditional telecommunication technologies than on technologies related to end-to-end networks. In the U.S., PCs and the Internet were identified earlier as the core technologies for entrance into the Information Society.

${ }^{\mathrm{v}}$ In 1993, 39 percent of French workers were operating a computer, while the rate was 46 percent in the U.S. However, in 1987, only 6.9 perceent of French households were equipped with a home PC, while the figure was 25 percent for the U.S (Greenan,1999)

${ }^{\mathrm{vi}}$ This late start and the catch up is confirmed by a set of indicators:

- Internet users: There were 15 Internet users per 100 inhabitants by the end of 1999 (EU average: 19), which was an increase of 77 percent since the end of 1998 (EU average: 51 percent) (ESIS, European Survey of Information Society Projects and Actions, 2000).

- Internet penetration within households: In April 2001, 21 percent of the French benefited from an Internet Connection at home, up from 8 percent in October 1999 (2 percent in 1997) (Heitzmann \& Loué, 2001). 
- Internet Hosts: The number of hosts under the suffix .fr grew more rapidly in France in the year 2000 than in the EU (+58 percent vs. +44 percent). For the second semester of the year 2000, French growth (25.1 percent) was even faster than the worldwide growth (17.8 percent) (SESSI, 2001b).

${ }^{\text {vii }}$ France is the country where broadband access to the Internet for households reaches the highest level in Europe (6 percent of the Individual Internet Subscribers have large band access). Two-thirds of these broadband subscribers rely on cable access. This data, however, must be balanced with figures for the U.S. (11.1 percent) and Korea (57.3 percent) (NetValue, 2001).

viii In the year 2000, the more intensive users of Minitel are the 40-70 years. The rate of equipment of the 40-49 (24 percent), 50-59 (23 percent) and 60-69 (17 percent) is higher than the French average (16 percent). Moreover, that rate did not decrease for the 50-69 over the last five years, while the under 50 clearly switched to the Internet. As an indicator, more households under 50 have a PC at home than the average (49 percent for 40 49 , and 44 percent for $18-40$ vs. 33 percent on average), and it strongly increased over the past four years (from 19 to 33 percent on average) (Mathonet \& Kaplan, 2002).

${ }^{\text {ix }}$ Almost 100 French on-line sellers survived the dot.com crash by the end of 2001. Among them 30 companies are already profitable. The profiling of these profit-making on-line sellers is stimulating. Less than 10 of them are pure players. Their common characteristic is to have adopted reasonable SME's strategies especially by not going international at first, and by consolidating a core business (that is not quite innovative most of the time). Main companies in this category include RueduCommerce, Paysan.org, Chapitre.com, Kelkoo. The remaining 20 profitable on-line sellers are all subsidiary of traditional big players: either retailers (e.g. Alapage, Fnac.com, Darty.com), or transportation companies (e.g. sncf.com). Interestingly most of them had previously developed on-line ordering over the Minitel (Source : Brousseau, 2002b) 